\title{
PENGARUH FINANCIAL LEVERAGE DAN PROFITABILITAS TERHADAP INCOME SMOOTHING DENGAN KUALITAS AUDIT SEBAGAI PEMODERASI
}

\author{
Rasinih $^{1}$ \\ Agus Munandar ${ }^{2}$ \\ ${ }^{1}$ Program Studi Akuntansi Universitas 17 Agustus 1945 Jakarta \\ e-mail : rasinih.iyas@yahoo.co.id \\ ${ }^{2}$ Program Studi Akuntansi Universitas 17 Agustus 1945 Jakarta
}

\begin{abstract}
ABSTRAK
Penelitian ini bertujuan untuk menguji pengaruh Financial Leverage dan Profitabilitas terhadap income smoothing dengan Kualitas Audit sebagai Moderating. Profitabilitas diukur dengan return on assets dengan rumus laba bersih dibagi total aktiva. Financial Leverage diukur dengan mencari perbandingan antara total kewajiban dengan total aset dari suatu perusahaan. Sedangkan Income smoothing dengan Indeks Perataan Laba dan Kualitas audit dengan dummy. Populasi dalam penelitian ini 134 perusahaan, dengan periode tahun 2011 sampai tahun 2013, Perusahaan yang dianalisis 20 perusahaan. Metode analisis data yang digunakan dari penelitian ini analisis regresi berganda. Namun sebelumnya, melakukan analisis statistik deskriptif dan uji asumsi klasik. Hasil penelitian ini menunjukkan variable financial leverage dan Profitabilitas berpengaruh dan signifikan terhadap income smoothing.
\end{abstract}

Kata Kunci : Financial Leverage, profitabilitas, Income smoothing, Kualitas audit

\begin{abstract}
This study aimed to examine the effect of Financial Leverage and Profitability against income smoothing with Quality Audit as a moderating. Profitability measured by return on assets formula net income divided by total assets. Financial Leverage is measured by finding the ratio between total liabilities and total assets of a company. Meanwhile, with the smoothing Income Gain Flattening Index and Quality audits with dummy. The population in this study 134 company, with the period of 2011 until 2013, the Company analyzed 20 companies. The method of analysis used data from this study multiple regression analysis. But earlier, descriptive statistical analysis and classical assumption. Results of this study show variable financial leverage and profitability and significant influence on income smoothing.
\end{abstract}

Keywords: Financial Leverage, profitability, income smoothing, Quality audit

\section{PENDAHULUAN}

Kemajuan dibidang ekonomi membuat munculnya kecurangan oleh orang yang tak bertanggung jawab salah satunya income smoothing. Menurut Koch (1981), income smoothing adalah cara yang digunakan untuk mengurangi variabilitas jumlah laba yang dilaporkan perusahaan agar sesuai dengan target yang diinginkan. Beberapa peristiwa skandal korporasi lainnya juga tidak terlewat dari tindakan para pemimpin perusahaan. Beberapa perusahaan yang terlibat dalam skandal tersebut contohnya: Enron, WorldCom, Tyco, HealthSouth, Global Crossing dan lain lain (Desjardins, 2011:3). Penyebab runtuhnya perusahaan raksasa di Amerika Serikat banyak yang diakibatkan karena adanya manipulasi pembukuan dan income smoothing, Sunarsip (2002) dalam Irianto (2003). Standar pelaporan keuangan yang tinggi ada cara lain yang memungkinkan bisa mengurangi praktik perataan laba yaitu meningkatkan kualitas pemeriksa laporan keuangan. Laba sebelum perataan laba didapat dengan mengurangi laba bersih dengan nilai Total Accruals (TA). Menurut Scott (2000:365), perusahaan cenderung melakukan income minimization saat memperoleh tingkat profitabilitas tinggi. Perusahaan yang mempunyai tingkat leverage yang tinggi diduga melakukan perataan laba karena perusahaan terancam default sehingga manajemen membuat kebijakan yang dapat meningkatkan pendapatan.

Menurut Jensen dan Meckling (1976), bahwa agency theory mendeskripsikan pemegang saham sebagai principal dan manajemen sebagai agen. Manajemen adalah pihak yang dikontrak sebagai pemegang saham untuk bekerja demi kepentingan dan kemakmuran pemegang saham. Untuk itu 
manajemen diberikan wewenang untuk membuat keputusan kepentingan terbaik bagi pemegang saham. Maka dari itu, manajer harus bertanggung jawab kepada pemegang saham. Unit analisis yang digunakan dalam teori keagenan adalah kontrak yang melandasi hubungan antara prinsipal dan agen. Penjelasan konsep manajemen laba menggunakan teori keagenan dan teori akuntansi positif. Teori keagenan menjelaskan bahwa praktik manajemen laba dipengaruhi oleh konflik kepentingan antara manajemen (agent) dan pemilik (principal) yang timbul karena adanya keinginan untuk memaksimalkan kemakmuran masing-masing.

Budiasih (2009) mendefinisikan bahwa income smoothing adalah tindakan yang dilakukan dengan sengaja untuk mengurangi variabilitas laba yang dilaporkan untuk dapat mengurangi resiko pasar atas saham perusahaan, yang pada akhirnya dapat meningkatkan harga saham perusahaan. Income smoothing merupakan salah satu bentuk kecurangan dalam laporan keuangan yang dapat merugikan perusahaan.

Financial leverage dapat mempengaruhi terjadinya income smoothing, yakni dimana kondisi financial leverage suatu perusahaan menjadi tekanan bagi pihak manajemen, karena ketika perusahaan memiliki rasio leverage yang besar maka direksi dan manajemen perusahaan akan memilih untuk menggunakan metode akuntansi yang akan mengecilkan rasio leverage perusahaan dengan cara menggeser laba periode mendatang ke periode saat ini (Watts dan Zimmerman, 1986). Ketika suatu perusahaan memiliki rasio leverage yang besar maka akan menciptakan kemungkinan untuk terjadinya kecurangan pelaporan keuangan yang dilakukan oleh direksi dan manajemen perusahaan dengan cara mengecilkan rasio leverage mereka dengan tujuan untuk mencapai kepentingan mereka yaitu memperoleh pinjaman kembali dan untuk membayar deviden kepada pemegang saham. Financial leverage diukur dengan debt to total asset yang diperoleh dari total utang dibagi dengan total aktiva. Perusahaan yang mempunyai tingkat leverage yang tinggi diduga melakukan perataan laba atau income smoothing karena perusahaan terancam default, maka manajemen meningkatkan kebijakan yang dapat meningkatkan pendapatan. Maka dapat diambil kesimpulan bahwa untuk hipotesis pertama penelitian ini. $\mathrm{H}_{1}$ : Financial leverage diduga berpengaruh positif terhadap income smoothing.

Profitabilitas dapat diukur dengan return on asset (ROA). ROA diperoleh dari laba bersih dibagi dengan total aktiva. Laba bersih tersebut merupakan laba sebelum dilakukan perataan laba. Laba sebelum perataan laba diperoleh dengan mengurangi laba bersih dengan nilai Total Accruals (TA). Menurut Scott (2000:365), perusahaan mayoritas melakukan income minimization saat memperoleh tingkat profitabilitas tinggi. Tingkat profitabilitas yang stabil akan memberikan keyakinan pada investor bahwa perusahaan tersebut memiliki kinerja yang baik dalam menghasilkan laba.

$\mathrm{H}_{2}$ : Profitabilitas diduga berpengaruh positif terhadap income smoothing.

Berdasarkan uraian pada pembahasan sebelumnya mengenai pengaruh financial leverage dan pengaruh profitabilitas terhadap income smoothing dengan kualitas audit sebagai moderating ditetapkan hipotesis ketiga.

$\mathrm{H}_{3}$ : Diduga Financial Leverage dan profitabilitas secara bersama-sama berpengaruh terhadap income smoothing.

Audit adalah suatu proses yang sistematis tentang akumulasi dan evaluasi terhadap bukti tentang informasi yang ada dalam suatu perusahaan tertentu. Merujuk pada penelitian terbaru yang dilakukan oleh The Committee of Sponsoring Organizations of The Treadway Commission (COSO), kecurangan dan perataan laba dalam pelaporan keuangan oleh perusahaan-perusahaan publik di Amerika Serikat memberikan konsekuensi yang tidak baik terhadap para investor dan eksekutif. Jumlah penipuan korporasi diperkirakan sekitar US\$ 600 juta per tahunnya (Frieswick, 2003), dan bertanggung jawab terhadap berkurangnya kepercayaan investor di pasar modal. Maka disimpulkan bahwa hipotesis keempat. $\mathrm{H}_{4}$ : Kualitas audit diiduga akan dapat memperkuat pengaruh financial leverage terhadap income smoothing.

Kualitas audit adalah salah satu variabel yang cenderung digunakan untuk menjelaskan mengenai variasi pengungkapan dalam laporan tahunan perusahaan. Terdapat beberapa penjelasan mengenai pengaruh profitabilitas terhadap kualitas ungkapan. Dalam suatu penelitian menyatakan bahwa perusahaan-perusahaan yang lebih besar memiliki dorongan untuk melakukan kecurangan dibandingkan dengan perusahaan-perusahaan yang lebih kecil karena perusahaan yang lebih besar diteliti dan dipandang dengan lebih kritis oleh para investor. Menurut Scott (2000:365), perusahaan cenderung melakukan income minimization saat memperoleh tingkat profitabilitas tinggi. Tingkat profitabilitas yang stabil akan memberikan keyakinan pada investor bahwa perusahaan tersebut memiliki kinerja yang baik 
dalam menghasilkan laba. Maka dapat disimpulkan bahwa hipotesis kelima.

$\mathrm{H}_{5}$ : Diduga kualitas audit akan dapat memperkuat pengaruh profitabilitas terhadap income smoothing.

\section{METODE PENELITIAN}

Metode analisis yang digunakan dalam penelitian ini yaitu analisis regresi berganda dengan menggunakan alat bantu IBM SPSS versi 16.0 dan menggunakan laporan keuangan tahunan yang diungkapkan oleh perusahaan yang listed di Bursa Efek Indonesia dari tahun 2011 - 2013. Jumlah sampel yang digunakan adalah 20 perusahaan yang listed di BEI selama periode 2011 - 2013. Metode pengambilan sampel menggunakan metode purposive sampling (judgement sampling) yang merumuskan beberapa kriteria dalam pengambilan sampelnya.

Adapun kriteria-kriteria yang digunakan dalam pengambilan sampel pembanding adalah sebagai berikut: 1) Bergerak dalam industri yang sama dengan perusahaan yang melakukan income smoothing; 2) Memiliki total aset yang sama atau mendekati dengan perusahaan yang tergolong melakukan income smoothing

Financial leverage adalah besarnya utang yang digunakan untuk membiayai operasi perusahaan. Selain itu, financial leverage juga didefinisikan sebagai perimbangan antara utang jangka panjang dengan struktur modal sendiri. Cara pengukuran financial leverage yaitu total liabilities terhadap total aset.

$$
\begin{gathered}
\mathrm{DFL}=\frac{\% \text { perubahan EAT } / \text { EPS atau Laba Bersih }}{\% \text { perubahan EBIT atau Laba Usaha }} \\
\text { DFLpadaX }=\frac{\frac{\Delta E P S}{\frac{E P S}{E B I T}}}{E B I T}
\end{gathered}
$$

Profitabilitas diukur menggunakan Return On Assets (ROA) yaitu rasio antara laba bersih dibagi dengan total aktiva (Brigham,2009:109). Laba bersih yang dimaksud adalah laba bersih sebelum dilakukan perataan laba.

Profitabilitas $=\frac{\text { Laba Bersih Sebelum Perataan Laba }}{\text { Total Aktiva }} \times 100 \%$...(3)

Untuk menentukan laba bersih sebelum perataan laba perlu diketahui besarnya peningkatan atau penurunan laba yang dilakukan oleh manajemen, yaitu dengan menghitung Total Accruals (TA) dari perusahaan. Kemudian Total Accruals tersebut digunakan sebagai penambah atau pengurang laba bersih perusahaan sehingga dapat diketahui laba sebenarnya. Adapun perhitungan Total Accruals sebagai berikut.

$$
\text { TAit }=\text { NIit }- \text { OCFit }
$$

$$
\text { Keterangan: }
$$

TAit = Total Accruals perusahaan i pada tahun $\mathrm{t}$ Nlit = Net Income perusahaan i pada tahun $\mathrm{t}$

OCFit = Arus kas (Operating Cash Flow) perusahaan i pada tahun $\mathrm{t}$

Proksi perataan laba yang digunakan untuk membedakan perata dengan bukan perata dalam penelitian ini adalah indeks excel dengan formula sebagai berikut :

Indeks Perataan Laba $=($ CV DI / CV DS $)$.......(5)

Dimana :

$\Delta \mathrm{I} \quad=$ Perubahan laba dalam satu periode

$\Delta \mathrm{S}=$ Perubahan penjualan dalam satu periode

$\mathrm{CV}=$ Koefisien variasi dari variabel, yaitu standar deviasi dibagi dengan nilai yang diharapkan. Dalam hal ini, nilai yang diharapkan menggunakan nilai rata-rata.

Jadi,

$\mathrm{CV} \Delta \mathrm{I}=$ Koefisien variasi untuk perubahan laba

$\mathrm{CV} \Delta \mathrm{S}=$ Koefisien variasi untuk perubahan penjualan.

CV DI dan CV DS dapat dihitung sebagai berikut:

$C V \Delta S=(D x \text { Penjualan }-D x \text { Penjualan })^{2} n-1: D x$

$C V \Delta I=(D x \text { Laba }- \text { Dx Laba })^{2} n-1: D x$

Dimana :

$\Delta \mathrm{x}$ penjualan $=$ perubahan penjualan

$\Delta \mathrm{x}$ Laba $=$ peubahan Laba

$\Delta \mathrm{X}$ penjualan $=$ rata-rata Perubahan penjualan

$\triangle \mathrm{X}$ laba $\quad=$ rata-rata Perubahan laba

$\mathrm{n} \quad=$ tahun yang diamati

Dasar pengambilan keputusan: 1) apabila Indeks Excel $\geq 1$ maka perusahaan adalah perata, dan 2) apabila Indeks Excel $<1$ maka perusahaan bukanlah perata laba.

Perhitungan indeks Excel dalam penelitian ini menggunakan alat bantu Microsoft Excel dengan memanfaatkan fungsi Standar Deviasi (stdev), Mean (average), dan fungsi hitung pembagian.

Kualitas Audit diukur dengan menggunakan dummy, yaitu 1 dan 0. Dimana 1 untuk Bigfour dan 0 untuk Non Big Four. 


\section{HASIL DAN PEMBAHASAN}

Jumlah sampel yang memenuhi kriteria di peroleh sampel sebanyak 20 perusahaan. Karena periode penelitian adalah selama 3 tahun, maka jumlah sub sampel yang di peroleh adalah 60 laporan keuangan (n sampel x periode penelitian). Populasi penelitian ini adalah seluruh perusahaan manufaktur yang tercatat di Bursa Efek Indonesia dengan periode pengamatan antara 2011 sampai dengan tahun 2013. Penelitian ini menggunakan regresi berganda namun sebelum itu maka di lakukan analisis statistik deskriptif dan uji asumsi klasik.

Berdasarkan Tabel uji t, dapat diketahui bahwa nilai t hitung 2,256 > t tabel 2,006 dan nilai signifikasi sebesar 0,028, maka dari hasil uji t ini dinyatakan Ho ditolak sehingga dapat dikatakan bahwa secara individu financial leverage berpengaruh terhadap Income smoothing (Hipotesis H1 diterima). Hasil ini konsisten dengan hasil penelitian Santoso (2009) yang menyatakan bahwa financial leverage berpengaruh positif dan signifikan pada perataan laba. Namun hasil penelitian dari Herawati dan Baridwan (2007) yang memberikan bukti empiris bahwa tidak ada kecenderungan perusahaan yang melanggar perjanjian utang, yang umumnya memiliki tingkat leverage tinggi melakukan manajemen laba lebih besar daripada perusahaan yang tidak melanggar perjanjian utang.
Berdasarkan Tabel uji t, dapat diketahui bahwa nilai t hitung -2,160 > t tabel 2,006, maka dari hasil uji $\mathrm{t}$ ini dinyatakan Ho ditolak sehingga dapat dikatakan bahwa secara individu Profitabilitas berpengaruh terhadap income smoothing (Hipotesis $\mathrm{H} 2$ diterima). Hasil penelitian ini konsisten dengan hasil penelitian Ashari et al. (1994), dan Budiasih (2009) yang mengemukakan profitabilitas berpengaruh terhadap income smoothing. Namun sesuai dengan penelitian Assih dkk. (2000), Suwito dan Herawaty (2005), serta Juniarti dan Corolina (2005) yang menyatakan bahwa Profitabilitas tidak berpengaruh terhadap income smoothing.

Dari Tabel anova diketahui nilai $\mathrm{F}$ hitung sebesar 5,089 dengan nilai signifikasi sebesar 0,028. Hasil uji anova antara variabel bebas terhadap variabel terikat diperoleh $\mathrm{F}$ hitung 5,089 > F tabel 3,168 dan tingkat signifikasi $0,028<0,050050$ maka H0 ditolak. Hal ini mengindikasikan bahwa secara simultan atau bersama-sama Financial Leverage dan Profitabilitas berpengaruh terhadap Perataan Laba (Hipotesis H3 diterima). Hal ini senada dengan pembuktian Hipotesis pertama namun dan hipotesis kedua sehingga dapat ditarik kesimpulan bahwa financial leverage dan profitabilitas bersama-sama berpengaruh terhadap perataan laba.

Berdasarkan Tabel ANOVA pada langkah pertama (analisis regresi untuk semua kategori sampel) diperoleh nilai Sum Square Residual sebesar

Tabel 1.

\begin{tabular}{lrrrrr}
\hline \multicolumn{7}{c}{ Coefficients $^{\mathbf{a}}$} \\
\hline & \multicolumn{2}{c}{$\begin{array}{c}\text { Unstandardized } \\
\text { Coefficients }\end{array}$} & $\begin{array}{c}\text { Standardized } \\
\text { Coefficients }\end{array}$ & & \\
\cline { 2 - 6 } Model & B & Std. Error & Beta & $\mathrm{t}$ & Sig. \\
\hline (Constant) & .724 & .170 & & 4.260 & .000 \\
X1 = Financial & .322 & .143 & .291 & 2.256 & .028 \\
Leverage & .32 & & & & \\
\hline
\end{tabular}

Sumber: Output IBM SPSS 16.0 (data diolah)

Tabel 2.

Coefficients $^{\mathrm{a}, \mathrm{b}}$

\begin{tabular}{lrrrrr}
\hline \multicolumn{7}{c}{$\begin{array}{l}\text { Unstandardized } \\
\text { Coefficients }\end{array}$} & $\begin{array}{c}\text { Standardized } \\
\text { Coefficients }\end{array}$ \\
\hline Model & B & Std. Error & Beta & t & \multicolumn{1}{c}{ Sig. } \\
\hline Constant $)$ & .705 & .185 & & 3.806 & .000 \\
X2 $=$ Profitabilitas & .316 & .146 & .303 & 2.160 & .036 \\
\hline
\end{tabular}

Sumber: Output IBM SPSS 16.0 (data diolah) 
Tabel 3.

\begin{tabular}{|c|c|c|c|c|c|c|}
\hline \multicolumn{7}{|c|}{ ANOVA $^{b}$} \\
\hline Model & $\begin{array}{l}\text { Sum of } \\
\text { Squares }\end{array}$ & \multicolumn{3}{|c|}{ df Mean Square } & $\mathrm{F}$ & Sig. \\
\hline Regression & 7.570 & & 1 & 7.570 & 5.089 & $.028^{\mathrm{a}}$ \\
\hline Residual & 81.820 & & 55 & 1.488 & & \\
\hline Total & 89.391 & & 56 & & & \\
\hline \multicolumn{7}{|c|}{$\mathrm{ANOVA}^{\mathrm{b}, \mathrm{c}}$} \\
\hline Model & $\begin{array}{l}\text { Sum of } \\
\text { Squares }\end{array}$ & \multicolumn{3}{|c|}{ df Mean Square } & $\mathrm{F}$ & Sig. \\
\hline Regression & 7.123 & & 1 & 7.123 & 4.665 & $.036^{\mathrm{a}}$ \\
\hline Residual & 70.235 & & 46 & 1.527 & & \\
\hline Total & 77.358 & & 47 & & & \\
\hline \multicolumn{7}{|c|}{ ANOVA $^{b, c}$} \\
\hline Model & $\begin{array}{l}\text { Sum of } \\
\text { Squares }\end{array}$ & df & & Mean Square & $\mathrm{F}$ & Sig. \\
\hline Regression & .338 & & 1 & .338 & .207 & $.663^{a}$ \\
\hline Residual & 11.417 & & 7 & 1.631 & & \\
\hline Total & 11.755 & & 8 & & & \\
\hline
\end{tabular}

Sumber: Output IBM SPSS 16.0 (data diolah)

81.820, diberi simbol SSRT. Berdasarkan Tabel ANOVA pada langkah kedua (analisis regresi untuk sampel dengan nilai 1 Big four auditor) diperoleh nilai Sum Square Residual sebesar 70,235, diberi simbol SSR1. Berdasarkan tabel ANOVA pada langkah ketiga (analisis regresi untuk sampel dengan nilai 0 / Non Big four auditor) diperoleh nilai Sum Square Residual sebesar, 11,417, diberi simbol SSR2. Berdasarkan tabel regresi untuk kategori sampel KAP Big four dan KAP non Big four diperoleh nilai Sum Square Residual Gabungan sebesar 409,455, yang diperoleh dari SSR $1+$ SSR2 $=81.652$ diberi simbol SSRG. Menghitung nilai $\mathrm{F}$ hitung dengan rumus sebagai berikut :

$$
F=\frac{(S S R T-S S R G) / k}{(S S R G) /(n 1+n 2-2 k)}
$$

Menurut penelitian Pujilestari dan Herusetya (2013) mengenai, Pengaruh Kualitas Audit Terhadap Manajemen Laba Transaksi Real - Pengakuan Pendapatan Strategis menyebutkan bahwa dalam Uji Sensitivitas dan Robustnes kualitas audit berpengaruh positif signifikan terhadap perataan laba. Hal ini membuktikan kualitas audit dengan proksi KAP Big four kurang mampu menekan dengan adanya perilaku manajemen dalam melakukan tindakan perataan laba.

\section{SIMPULAN}

Berdasarkan pembahasan yang telah dijabarkan sebelumnya maka dapat ditarik kesimpulan bahwa: 1) Dalam pengujian parsial ditemukan bahwa Financial Leverage berpengaruh signifikan terhadap income smoothing; 2)Dalam pengujian parsial ditemukan bahwa profitabilitas berpengaruh signifikan terhadap income smoothing; 3) Dalam pengujian bersama-sama Financial Leverage dan profitabilitas berpengaruh terhadap income smoothing.

Keterbatasan yang membawa dampak pada hasil penelitian ini antara lain : 1) Pada penelitian ini menggunakan waktu yang relatif singkat dan hanya pada perusahaan manufaktur saja; 2) Pada penelitian ini hanya menggunakan 20 perusahaan sampel yang di dapat dari metode purposive sampling; 3) Sulit mendapatkan data perusahaan yang melakukan 
kecurangan akuntansi keuangan; 4) Variabel bebas yang diteliti hanya 2 variabel saja sehingga kemampuan variabel bebas dalam menerangkan variabel terikatnya masih terbatas.

Berdasarkan hasil penelitian ini, ada beberapa saran yang diajukan oleh peneliti yang mungkin nantinya bisa dipertimbangkan untuk penelitian selanjutnya agar menjadi lebih baik diantaranya adalah : 1) Penelitian selanjutnya diharapkan menambahkan variabel bebas lainnya atau variabel moderating lainnya dalam penelitian berikutnya seperti Net Profit Margin dan lain - lainnya; 2) Penelitian selanjutnya diharapkan tidak hanya melakukan pada perusahaan manufaktur saja tetapi memasukkan perusahaan dari sektor lain sehingga menggambarkan secara menyeluruh keadaan perusahaan go public; 3) Penelitian selanjutnya diharapkan menambahkan periode pengamatannya sehingga kualitas penelitiannya akan lebih baik.

\section{REFERENSI}

Ashari, N., Koh, H.C., Tan, S.L. dan Wang. W.H. 1994. Factor Affecting Income Smoothing Among Listed Companies in Singapore. Accounting Business Research, Vol 24 (96). Hal 291-301.

Assih, Prihat., dan M.Gudono. 2000. Hubungan Tindakan Perataan Laba terhadap Reaksi Pasar atas Pengumuman Imormasi Laba Perusahaan yang Terdaftar di BEJ. Jurnal Riset Akuntansi Indonesia, Vol.3, No.1, Hal.35-53.

Brigham, Eugene F., Joel F. Houston. 2009. Fundamentals of Financial Management. Jakarta: Salemba Empat

Budiasih, Igan. 2009. Faktor-Faktor yang Mempengaruhi Praktik Perataan Laba. Jurnal Akuntansi Bisnis, Vol. 4 No. 1. Januari. hal: 44-50.

Desjardins, J dan Hartman, L. 2011. Etika Bisnis: Pengambilan Keputusan untuk Integritas Pribadi dan Tanggungjawab Sosial. Jakarta : Penerbit Erlangga.

Frieswick, K. 2003. How Audits Must Change. CFO, 1 Juli: 1.

Gagola, Antonius Stany Christo. 2011. Analisis Faktor Risiko yang Mempengaruhi Kecenderungan
Kecurangan Pelaporan Keuangan Perusahan Publik di Indonesia. Tesis. Undip.

Herawati, Nurul dan Zaki, Baridwan. 2007. Manajemen Laba pada Perusahaan yang Melanggar Hutang. Simposium Nasional Akuntansi X. Makasar.

Irianto, G. 2003. Skandal Korporasi dan Akuntan. Lintasan Ekonomi. Vol. XX No. 2 bulan Juli halaman 104-110.

Jensen, Michael C., dan William H. Meckling, 1976. Theory of The Firm: Managerial Behavior, Agency and Ownership Structure . Journal of Financial Economic. Vol. V 3, No.4, October, pp. 305-360.

Juniarti dan Carolina. 2005. Analisa Faktor-Faktor yang Berpengaruh Terhadap Perataan Laba (Income Smoothing) Pada Perusahaan-Perusahaan Go Public.Jurnal Akuntansi \& Keuangan. Vol. 7 No. 2. Nopember. hal: 148- 162.

Koch, Bruce S, 1981, Income Smoothing : An Experient, The Accounting Review, Juli: 574-586.

Santoso. 2009. Panduan Lengkap Menguasai Statistik dengan SPSS. Jakarta: PT. Elex Media Komputindo.

Scott, William R. 2000. Financial Accounting Theory. Second edition. Canada: Prentice Hall.

Sunarsip. Menarik Pelajaran dari Skandal Korporasi di AS, Kompas 15 Juli 2002.

Suwito dan Herawaty. 2005. Analisis Pengaruh Karakteristik Perusahaan terhadap Tindakan Perataan Laba yang dilakukan oleh Perusahaan yang Terdaftar di Bursa Efek Jakarta. SNA VIII Solo. September.

The Committee of Sponsoring Organization of the treadway Commission, COSO (1992): COSOInternal Control Integrated Framework, The Committee of Sponsoring Organization of the treadway Commission.

Watts, R, L., and Zimmerman, J, L. 1986, Positive Accounting Theory. New York, Prentice Hall.

Wilopo. 2006. Analisis Faktor-faktoryang Berpengaruh Terhadap Kecenderungan Kecurangan Akuntansi. STIE Perbanas, 2006.

Koch, Bruce S. 1981. Income Smoothing: An Experiment. Accounting Review. July: 574-586. 